\title{
The Implementation of Balanced Nutrition Using "Piring Makanku" on Food Consumption of Orphanage Children in Makassar City
}

\author{
Nurhaedar Jafar ${ }^{1 *}$, Amaliah Chairul Nusu ${ }^{1}$, Suriah Suriah ${ }^{2}$ \\ ${ }^{1}$ Department of Nutrition, Faculty of Public Health, Hasanuddin University, Makassar, Indonesia; ${ }^{2}$ Department of Health \\ Promotion and Behavioral Sciences, Faculty of Public Health, Hasanuddin University, Makassar, Indonesia
}

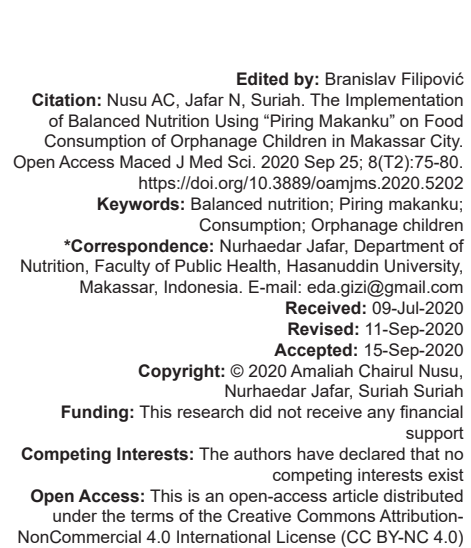

Introduction

Each country has food-based dietary guideline (FBDG), such as the Food Guide Pyramid in the US, The Thai Nutrition Flag in Thailand, and in Indonesia known as Balanced Nutrition Guidelines (PGS). This guideline is based on the characteristics of the population including habits, socioculture, and science and technology development.

The evidence supporting the guidelines has a broad base but focuses on the relation between food consumption and disease prevention. From this evidence base, diet models can be constructed and translated into food guidance tools, including diagrammatic representations, such as plates or pyramids [1].

The main purpose of eating guidelines is to improve public health and prevent nutritional problems. This objective is evident from several international literatures that adherence to national eating guidelines has an impact on nutritional and health conditions. Hansen et al. [2] research concluded that adherence to national FBDG in Denmark was associated with a lower risk of myocardial infarction.

In South Sulawesi, data of Riskedas 2013 showed the prevalence of underweight based on body mass index for age (BMI/U) in school-aged children (5-12 years) higher than the national rate, then the prevalence of wasting and severe wasting (BMI/U) school-aged children (13-15 years) is higher than the national average [3].

The data of Riskesdass showed that the balanced nutrition guideline has not work optimally. Attention needs to be addressed seriously in the school age because children and adolescents are in a period of rapid growth. In the period of rapid growth, nutritional intake can inhibit the function of the growth process.

One of the main targets of PGS is social institutions such as orphanages. School-aged children living in orphanages are particularly vulnerable to problems of nutrition and health as well as being neglected in society. Research of Mwaniki et al. [4] in Kenya showed that significantly more orphanage children experienced stunting, wasting, and a higher level of morbidity $(p<0.005)$. 
To spread balanced nutrition guidelines, campaign of isi piringku was held by the Ministry of Health in 2018. In these activities, participants brought breakfast supplies using a container in accordance with piring makanku dishware.

The use of plate media can be used as new strategy in controlling the amount of food consumed and the impact on food intake in the body. McClain et al. [5] study concluded that small changes in plate design have the potential to produce relatively greater effects on the amount of food perceive and thus will have an impact on intake in body.

Piring makanku, or a one-off meal, intended as a guide that shows the food at each meal (e.g., breakfast, lunch, and dinner). Visual of piring makanku suggests that eating the portion of vegetables should be more than the portion of fruit and the portion of staple food more than protein dish [6].

To prevent the emergence of nutritional problems, balanced nutrition guidelines need to be socialized as eating guidelines based on the four pillars of balanced nutrition. This current study aims to assess the implementation of balanced nutrition guidelines using piring makanku on food consumption of orphanage children in Makassar city.

\section{Materials and Methods}

This research was conducted 16 days in two orphanages in the Makassar city, those orphanages were panti asuhan mulia and panti asuhan resky ananda. This research uses quantitative methods with quasi-experimental design and uses a non-randomized pretest-posttest with the control group design.

Population in this study are all of children living in panti asuhan mulia and panti asuhan resky ananda. A total of 60 samples were selected purposively with the inclusion criteria which were children aged 13-18, approved informed consent, and not suffering chronic nutritional problems. The total sample was divided into two groups, each of the 30 samples in the treatment group received nutrition education and piring makanku, and 30 samples in the control group received nutrition education only. This study was approved by the Ethics Committee of the Faculty of Public Health at the University of Hasanuddin Makassar.

Subject characteristics data were obtained from orphanage records and questionnaires, nutritional status obtained through anthropometric measurement, food consumption were obtained through interviews using $2 \times 24 \mathrm{~h}$ food recall (weekday and weekend) at the beginning and end of the study.

Data related to piring makanku include preference on piring makanku obtained through a questionnaire, compliance of the use of piring makanku obtained through a control card based on the use at dinner time, the practice of using piring makanku obtained by observation at lunch and dinner for 8 meals times, and portion acceptability received from questionnaire that submitted $15 \mathrm{~min}$ after the subjects consumed the food served using piring makanku with the same portion and type of food in the treatment group.

Subject's characteristics, nutritional status, compliance and practice of using piring makanku, and portion acceptability were processed and analyzed using SPSS 24 program for Windows. Food intake data are processed using NutriSurvey software and analyzed using SPSS program. Data of the characteristics, nutritional status, and consumption (intake) of subjects in the two study groups used t-test for paired and nonpaired groups.

\section{Results}

\section{Characteristics of sample}

The age of the subjects ranged from 13 to 18 years. Most subjects were 13-14 years old both in the treatment group (56.7\%) and in the control group $(40 \%)$ (Table 1). In general, the proportion of subjects in both groups was almost the same between junior high school (53.3\%) and senior high school (46.7\%), but in the treatment group, it was slightly more dominant in subjects with junior high school education (56.7\%) (Table 1).

In this study, most of the subjects were low economic families (80\%), only few of them were orphans and abandoned. The results of the Mann-Whitney

Table 1: Characteristics of orphanage children

\begin{tabular}{|c|c|c|c|c|c|c|c|}
\hline \multirow[t]{3}{*}{ Subject characteristics } & \multicolumn{4}{|c|}{ Group } & \multirow{2}{*}{\multicolumn{2}{|c|}{$\begin{array}{l}\text { Total } \\
(\mathrm{n}=60)\end{array}$}} & \multirow[t]{3}{*}{$\mathrm{p}$-value } \\
\hline & \multicolumn{2}{|c|}{$\begin{array}{l}\text { Treatment } \\
(\mathrm{n}=30)\end{array}$} & \multicolumn{2}{|c|}{$\begin{array}{l}\text { Control } \\
(n=30)\end{array}$} & & & \\
\hline & $\mathrm{n}$ & $\%$ & $\mathrm{n}$ & $\%$ & $\mathrm{n}$ & $\%$ & \\
\hline Gender & & & & & & & 0.277 \\
\hline Male & 8 & 26.7 & 12 & 40.0 & 20 & 33.3 & \\
\hline Female & 22 & 73.3 & 18 & 60.0 & 40 & 66.7 & \\
\hline Age (years) & & & & & & & 0.242 \\
\hline $13-14$ & 17 & 56.7 & 12 & 40.0 & 29 & 48.3 & \\
\hline $15-16$ & 7 & 23.3 & 10 & 33.3 & 17 & 28.3 & \\
\hline $17-18$ & 6 & 20.0 & 8 & 26.7 & 14 & 23.3 & \\
\hline Class grade & & & & & & & 0.809 \\
\hline VII & 7 & 23.3 & 10 & 33.3 & 17 & 28.3 & \\
\hline VIII & 5 & 16.7 & 4 & 13.3 & 9 & 15.0 & \\
\hline IX & 5 & 16.7 & 1 & 3.3 & 6 & 10.0 & \\
\hline$x$ & 1 & 3.3 & 3 & 10.0 & 4 & 6.7 & \\
\hline $\mathrm{XI}$ & 8 & 26.7 & 7 & 23.3 & 15 & 25.0 & \\
\hline XII & 4 & 13.3 & 5 & 16.7 & 9 & 15.0 & \\
\hline Level of education & & & & & & & 0.608 \\
\hline Junior high school & 17 & 56.7 & 15 & 50.0 & 32 & 53.3 & \\
\hline Senior high school & 13 & 43.3 & 15 & 50.0 & 28 & 46.7 & \\
\hline Orphanage children status & & & & & & & $0.006^{*}$ \\
\hline Low economic families & 28 & 93.3 & 20 & 66.7 & 48 & 80 & \\
\hline Loss of father & 2 & 6.7 & 0 & 0 & 2 & 3.3 & \\
\hline Loss of mother & 0 & 0 & 2 & 6.7 & 2 & 3.3 & \\
\hline Orphan & 0 & 0 & 7 & 23.3 & 7 & 11.7 & \\
\hline Abandoned & 0 & 0 & 1 & 3.3 & 1 & 1.7 & \\
\hline
\end{tabular}


U-test, there were significant differences in orphanage status of subject ( $p=0.006$ ) between the two groups (Table 1).

\section{Nutritional status}

Most $(75 \%)$ of the subjects in both groups was dominated by normal nutritional status ( -2 SD to +1 SD) based on BMI/U. The proportion of overweight status $(21.7 \%)$ was more than underweight subject $(3.3 \%)$ in both groups (Table 2). Statistical test results showed no significant difference ( $p>0.05$ ) on Z-score mean of $\mathrm{BMI} / \mathrm{U}$ between the two study groups (treatment and control) (Table 2).

Table 2: Nutritional status

\begin{tabular}{|c|c|c|c|c|c|c|c|}
\hline \multirow[t]{3}{*}{ Nutritional status } & \multicolumn{4}{|c|}{ Group } & \multirow{2}{*}{\multicolumn{2}{|c|}{$\begin{array}{l}\text { Total } \\
(n=60)\end{array}$}} & \multirow[t]{3}{*}{ p-value } \\
\hline & \multicolumn{2}{|c|}{$\begin{array}{l}\text { Treatment } \\
(n=30)\end{array}$} & \multicolumn{2}{|c|}{$\begin{array}{l}\text { Control } \\
(n=30)\end{array}$} & & & \\
\hline & $\mathrm{n}$ & $\%$ & $\mathrm{n}$ & $\%$ & $\mathrm{n}$ & $\%$ & \\
\hline Underweight (-3 SD s/d <-2 SD) & 2 & 6.7 & 0 & 0 & 2 & 3.3 & 0.456 \\
\hline Normal (-2 SD s/d +1 SD) & 22 & 73.3 & 23 & 76.7 & 45 & 75. & \\
\hline Overweight (>1 SD s/d +2 SD) & & 20.0 & 7 & 23.3 & 13 & 21.7 & \\
\hline
\end{tabular}

\section{Food consumption (nutrient intake)}

Table 3 shows the increase mean of energy intake after the intervention in the treatment group $(1727.17 \pm 271.12 \mathrm{kcal})$ and the control group (1615.34 $\pm 168.39 \mathrm{kcal})$. A very significant difference in the treatment group with an average change of $151.59 \pm$ $229.42 \mathrm{kcal}$ is greater than in the control group. Statistical test results showed a significant $p$ value $(p<0.05)$ in

Table 3: Change of nutrient intake mean at before and after the intervention

\begin{tabular}{|c|c|c|c|}
\hline \multirow{2}{*}{ Nutrient intake } & \multicolumn{2}{|l|}{ Group } & \multirow[t]{2}{*}{$p$-value } \\
\hline & Treatment $(n=30)$ & Control $(n=30)$ & \\
\hline \multicolumn{4}{|l|}{ Energy } \\
\hline \multicolumn{4}{|l|}{ Pre-test } \\
\hline Mean $\pm S D(k c a l)$ & $1575.57 \pm 99.39$ & $1570.53 \pm 322.72$ & 0.329 \\
\hline \multicolumn{4}{|l|}{ Post-test } \\
\hline Mean $\pm \mathrm{SD}(\mathrm{kcal})$ & $1727.17 \pm 271.12$ & $1615.34 \pm 168.39$ & 0.383 \\
\hline$p$-value & $0.002^{*}$ & 0.349 & \\
\hline$\Delta$ & $151.59 \pm 229.42$ & $44.80 \pm 261.87$ & 0.098 \\
\hline \multicolumn{4}{|l|}{ Protein } \\
\hline \multicolumn{4}{|l|}{ Pre-test } \\
\hline Mean \pm SD (gr) & $34.18 \pm 3.26$ & $50.08 \pm 10.97$ & $0.000^{*}$ \\
\hline \multicolumn{4}{|l|}{ Post-test } \\
\hline Mean \pm SD (gr) & $61.60 \pm 9.23$ & $58.33 \pm 12.11$ & 0.154 \\
\hline$p$-value & $0.000^{*}$ & $0.005^{*}$ & \\
\hline$\Delta$ & $27.42 \pm 9.05$ & $8.25 \pm 14.81$ & $0.000^{*}$ \\
\hline \multicolumn{4}{|l|}{ Fat } \\
\hline \multicolumn{4}{|l|}{ Pre-test } \\
\hline Mean \pm SD (gr) & $50.54 \pm 5.53$ & $38.62 \pm 18.16$ & $0.007^{*}$ \\
\hline \multicolumn{4}{|l|}{ Post-test } \\
\hline Mean \pm SD (gr) & $53.14 \pm 5.78$ & $46.21 \pm 22.94$ & $0.034^{*}$ \\
\hline$p$-value & 0.080 & $0.043^{*}$ & \\
\hline$\Delta$ & $2.6 \pm 7.79$ & $7.59 \pm 25.18$ & 0.307 \\
\hline \multicolumn{4}{|l|}{ Carbohydrate } \\
\hline \multicolumn{4}{|l|}{ Pre-test ${ }^{4}$} \\
\hline Mean \pm SD (gr) & $243.56 \pm 16.14$ & $245.26 \pm 62.24$ & 0.886 \\
\hline \multicolumn{4}{|l|}{ Post-test } \\
\hline Mean \pm SD (gr) & $231.07 \pm 54.86$ & $229.41 \pm 45.38$ & 0.751 \\
\hline $\mathrm{p}$-value & $0.024^{*}$ & 0.214 & \\
\hline$\Delta$ & $-12.48 \pm 50.92$ & $-15.85 \pm 68.38$ & 0.348 \\
\hline \multicolumn{4}{|l|}{ Fiber } \\
\hline \multicolumn{4}{|l|}{ Pre-test } \\
\hline Mean \pm SD (gr) & $8.88 \pm 0.81$ & $8.04 \pm 2.74$ & 0.886 \\
\hline \multicolumn{4}{|l|}{ Post-test } \\
\hline Mean \pm SD (gr) & $8.74 \pm 2.08$ & $7.98 \pm 2.34$ & 0.751 \\
\hline$p$-value & 0.650 & 0.837 & \\
\hline$\Delta$ & $-0.14 \pm 2.05$ & $-0.06 \pm 3.36$ & 0.908 \\
\hline
\end{tabular}

the treatment group before and after the intervention $(p=0.002)$, which means that there were differences in energy intake before and after the intervention.

The average protein intake in Table 3 showed an increase after intervention in each group, the statistical test showed a significant $p$-value in the treatment group ( $p=0.000)$. In the control group, the statistical test also showed a significant $p$ value $(p=0.005)$, it means that there were differences in protein intake after the intervention. For the average change between groups, the results still show that $p$ value is significant $(p=0.000)$.

Statistical test results of fat intake mean between groups in Table 3 show significant $p$ values $(p<0.05)$ both before $(p=0.007)$ and after intervention $(p=0.034)$. Although the mean value of fat intake in the treatment and control groups was not significant enough the changes $(2.6 \pm 7.79 \mathrm{gr}$ and $7.59 \pm 25.18$ $\mathrm{gr}$ ), the mean values of intake between groups before and after the intervention were quite different.

Carbohydrate intake mean value of subjects in Table 3 decreased by $-12.48 \pm 50.92 \mathrm{gr}$ in the treatment group and as much as $-15.85 \pm 68.38 \mathrm{gr}$ in the control group after the intervention. After conducting statistical tests between groups and in each group, there was no significant $p$ value, except in the treatment group $(p=0.024)$ which means that there were differences in carbohydrate intake before and after the intervention.

Table 3 shows that there was a change in the fiber intake mean in each group after the intervention, where there was an increase intake in the treatment group $(0.14 \pm 2.05 \mathrm{gr})$ and a decrease intake in the control group $(-0.06 \pm 3.36 \mathrm{gr})$. Statistical test results showed a value of $p>0.005$ which means that there was no difference in the fiber intake mean between before and after the intervention both in each group, between groups, and the average change in protein intake $(p=0.908)$.

\section{The use of piring makanku}

Table 4 shows that the mean of subject compliance was categorized as moderate (68.32 \pm 3.59), some subjects using piring makanku 9 times

Table 4: Mean of the use of piring makanku scores in the treatment group

\begin{tabular}{lll}
\hline Variables & Total & $(\%)$ \\
\cline { 2 - 3 } & $\mathrm{n}(30)$ & 0 \\
\hline Compliance & 0 & 43,3 \\
Poor (<60) & 13 & 56,7 \\
Moderate $(60-80)$ & 17 & \\
High $(>80)$ & $68.32 \pm 3.59$ & 43.3 \\
Mean \pm SD $(\%)$ & & 23.3 \\
Practice & 13 & 33.3 \\
Poor $(<60)$ & 7 & \\
Moderate $(60-80)$ & 10 & 70.0 \\
High $(>80)$ & $63.33 \pm 31.64$ & 26.7 \\
Mean \pm SD $(\%)$ & 21 & 3.3 \\
Portion acceptability & 8 & \\
Good $(>80)$ & 1 & \\
Enough $(60-80)$ & $86.25 \pm 14.06$ & \\
Less $(<60)$ & & \\
Mean \pm SD (\%) & &
\end{tabular}


$(43.3 \%)$ and some using 10 times (56.7\%) with the total of 14 days of intervention. There was a difference in the level of compliance due to activities at the orphanage.

Table 4 also shows that most subjects were categorized as poor practice (43.3\%) with the mean score of $63.33 \pm 31.64$ (medium category). The assessment of the practice of using piring makanku based on direct observation by focus on two aspects of the assessment, includes the diversity of food types and portions in accordance with the visual recommendations of piring makanku. In addition, most of the subject portion acceptance is categorized as good (70\%), which means that the portion of food given to the subject is in accordance with what they can consume without waste or adding the standard portion of food.

Thus, the use of piring makanku in this study was still not optimal. There are three variables assessed, only the variable of portion acceptance was categorized as good, the rest of the compliance and practice variables were categorized as moderate.

Figure 1 shows that most subjects evaluated piring makanku model to be quite interesting $(53.3 \%)$. Piring makanku model is designed based on visualization and recommended portion of piring makanku. In terms of color, $76.7 \%$ of subjects rated the color quite interesting with the natural color of wood. While in terms of size, more than half of the subjects rated it quite heavy $(76.7 \%)$, this is in accordance with the raw material used for plate was wood.

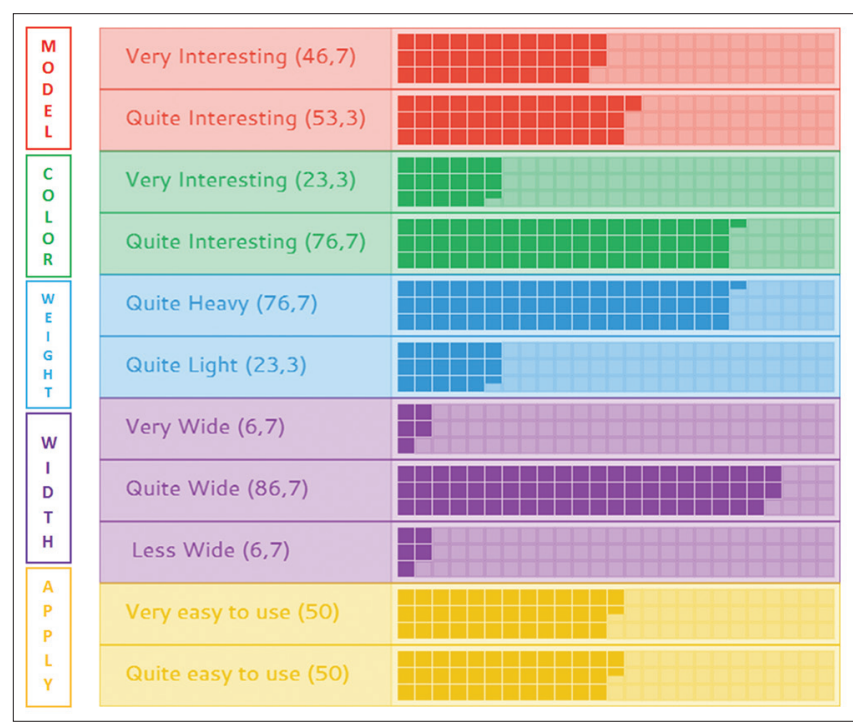

Figure 1: Presentation of preference on piring makanku in the treatment group

Figure 1 also shows most subjects stated that the plate was quite wide $(86.7 \%)$. In terms of use, all subjects rated it easy to use that is very easy to use $(50 \%)$ and quite easy to use (50\%). Subjects who previously used ordinary plates without the compartment model needed to adapt.

In general, the assessment of the subject's preference for piring makanku needs to be evaluated in terms of the choice of raw materials and colors used to create an attractive impression for the user, in the further development of piring makanku dishware.

\section{Discussion}

In this study, the characteristics and nutritional status of the subjects in the two study groups were almost the same and most of the subjects had normal nutritional status. This condition illustrates that the availability of food in an orphanage can be assumed to be sufficient in terms of quantity. For food consumption, most subjects had less energy intake. This condition illustrates that the nutrient intake of subjects is not adequate in terms of quality and quantity.

School-aged children living in social institutions such as orphanages face a high risk of early malnutrition, low intellectual maturity, and loss of closeness to family [7]. This age is a teenager who is very easily influenced in determining lifestyle and eating behavior. However, the problem generally faced by orphanage children is lack of access to information and limited facilities to support child development.

Children in orphanage did not only come from parents who have passed away, but most of them come from families with low economic conditions. Theoretically, neglect is an intentional or unintentional act that leaves the child unmet for his basic needs (clothing, shelter, and food) [8]. As in this study, predominantly, orphans come from poor families. This condition is in line with the case study of child neglect in Surabaya that parents consider sending children to an orphanage due to family economic factors, because the orphanage not only provides shelter and daily food but also provides education guarantees [8].

The distribution of the nutritional status data subjects in this study showed that most of the subjects had normal nutritional status. These results are consistent with the previous studies related to studies of nutritional behavior of orphanages in Malaysia that most respondents were in the range of normal BMI [7].

There was an increase in the average energy intake after the intervention, but most of the subjects were categorized as deficit in the two groups. These results are consistent with the results of the survey total diet 2014 showed that mean of energy intake of teenagers in rural and urban classified as deficit in all provinces in Indonesia when compared with recommended daily allowance (RDA) for energy [9].

When compared with RDA 2019, RDA for energy generally amounted to $2100 \mathrm{kcal} /$ day, mean of energy intake in the treatment group could considered 
good, whereas the control group categorized as deficit. Based on the results of statistical tests, it appears that there are differences in energy intake before and after treatment in the intervention group.

For protein intake, when compared with RDA 2019, RDA for protein in general by 57 g/day, therefore, the average intake of protein in both study groups can be categorized as good. Statistical test results showed that there were differences in protein intake mean after intervention in the two groups.

Then for fat intake, when compared with RDA 2019, RDA for fat generally equal to $68 \mathrm{~g} /$ day, fat intake mean of subject on both groups categorized as deficit. The results of statistical tests between groups showed that there were differences in the subject's protein intake both before and after the intervention.

Furthermore, for carbohydrate intake, the results of statistical tests did not show a significant value. If based on the RDA 2019, the recommended consumption of carbohydrates for school-aged children (10-18 years) is 280-300 kcal for women and $300-400 \mathrm{kcal}$ for men, so it can be said that the average carbohydrate intake of subjects is categorized as deficit.

For fiber intake, mean intake between the treatment and control groups was almost same before and after the intervention which ranged from 7 to $9 \mathrm{gr}$. If based on the RDA 2019, the recommended fiber consumption is 28-37 grams in school-aged children, which mean that fat intake mean before and after the intervention is very far from the recommendation intake expected intake (categorized as deficit). According to Akseer et al. [10], food choices in conditions of limited resources are limited by high levels of poverty, causing food insecurity, low food diversity, and lack of access to nutritious food.

In general, intake mean of nutrients after an intervention has increased except for carbohydrates. School age is a rapid level of growth for children, but it is very susceptible to disease so nutritional education needs to be provided regarding healthy living behaviors especially those related to balanced nutrition guidelines [11].

By carrying out the PGS socialization program into a community nutrition education program, it can provide many benefits, one of which is in terms of children's nutrient intake [11]. According to Ekundayo et al. [12] that orphans or children living in orphanages are faced with survival problems, they continue to look for information but one gap that has not been completely closed in meeting the basic needs of orphanages by various stakeholders is the provision of health information adequately.

This study showed mean of score compliance using piring makanku categorized as moderate. During the
14 days of intervention, about 4-5 days the subject did not use piring makanku because the subject received a donated rice box. Therefore, the good effect of piring makanku on food consumption can be influenced by the level of subject compliance which is not good. The results of this study are similar to the findings of MacKenzie-Smith et al. [13] (2018), the study found that patient preference for drug formulations triggers patient adherence, therefore to improve patient adherence must be involved in the selection of treatment formulations.

Meanwhile, the results of observing the practice of using piring makanku showed that most subjects received poor practice scores because they did not follow the suitability of piring makanku portions. The highest number of errors in the subject was the discrepancy in the portion of vegetables taken with the recommended portion of piring makanku.

Research by Disantis et al. [14] shows that children serve themselves more with larger plate and bowl sizes and consume nearly $50 \%$ of the calories served. This provides new evidence that children's independent portion sizes are influenced by the size of the condition of the eating utensils around their food, which, in turn, can affect children's energy intake.

In general, the subject's awareness of fruit and vegetable consumption is quite good, but in practice, it has not been categorized as good for a vegetable portion because it does not meet the recommended portion of piring makanku. Children generally know the importance of nutrition but they do not care about health benefits of food in food choices.

As recommended by Ministry of Health Republic of Indonesia, therefore, piring makanku in this study has been specifically designed according to the Ministry of Health's recommendations. The goal is to facilitate the subject in measuring various types of food consumed according to portions.

The balanced nutrition guideline introduces piring makanku term to make it easier to determine the type and amount of food consumed at each meal. This is important to note because in the current era of globalization, there is an increase in the amount or portion of food with foods that contain lots of fat. Dimensions pleasure to follow the needs of sensory pleasure seeking, social, and contextual experiences of food consumption [15], [16], [17].

The effect of food portion size is known to correlate with excess calorie consumption and weight gain, exacerbated by the human tendency to spend all food on a plate. According to Benton [18], when the children are offered food that conformed with age, or twice the size of the bite size results or food eaten will increases. Thus, the implementation of PGS needs to be familiarized early to control food portions in children. 


\section{Conclusion}

\section{Recommendation}

There is an effect of combined intervention of nutrition education and piring makanku dishware on the subject's food consumption (energy, protein, and carbohydrate intake), and nutrition education intervention on the subject's food consumption (protein and fat intake). However, there was no significant difference in mean of nutrients intake (energy, carbohydrates, and fiber) between groups after the intervention, while there was a significant difference between changes of protein and fat intake mean between groups after the intervention. Thus, the two forms of intervention in this study have almost the same effect on the subject's food consumption, except protein and fat intake. As a vulnerable group, children of orphanages need to pay attention to their nutritional and health conditions. In addition, campaign of isi piringku using piring makanku needs to be made in the form of lunch boxes to school.

\section{References}

1. Tapsell LC, Neale EP, Satija A, Hu FB. Foods, nutrients, and dietary patterns: Interconnections and implications for dietary guidelines. Adv Nutr. 2016;7(3):445-54. https://doi.org/10.3945/ an. 115.011718

2. Hansen CP, Overvad K, Tetens I, Tjønneland A, Parner ET, Jakobsen MU, et al. Adherence to the Danish food-based dietary guidelines and risk of myocardial infarction: A cohort study. Public Health Nutr. 2018;21(7):1286-96. https://doi. org/10.1017/s1368980017003822

PMid:29331164

3. Kemenkes RI. Riset Kesehatan Nasional 2014. Jakarta: Kementerian Kesehatan Republik Indonesia; 2014.

4. Mwaniki EW, Mokokha AN, Muttunga JN. Nutrition status and associated morbidity risk factors among orphanage and nonorphanage children in selected public primary schools within Dagoretti, Nairobi, Kenya. East Afr Med J. 2014;91(9):289-97. https://doi.org/10.4314/ahs.v13i1.6

PMid:26866080

5. McClain AD, Van Den Bos W, Matheson D, Desai M, Robinson TN. Visual illusions and plate design: The effects of plate rim widths and rim coloring on perceived food portion size. Int J Obes (Lond). 2014;38(5):657-62. https://doi.org/10.1038/ ijo.2013.169

\section{PMid:24005858}

6. Kemenkes RI. Pedoman Gizi Seimbang. Jakarta: Kementerian Kesehatan Republik Indonesia; 2014.

7. Bin-Shaziman S, Rani MD, Aripin KB, Hamid NA, Sulaiman WN Rahman ZA. Assessing nutritional knowledge, attitudes and practices and body mass index of adolescent residents of orphanage institutions in Selangor and Malacca. Pak J Nutr. 2017;16(6):406-11. https://doi.org/10.3923/pjn.2017.406.411

8. Basnur RR. Orang tua yang menitipkan anak ke panti asuhan di Surabaya. J Komun. 2014;3(3):1-11.

9. Kemenkes RI. Riset Kesehatan Dasar 2013. Jakarta: Kementerian Kesehatan Republik Indonesia; 2013.

10. Akseer N, Al-Gashm S, Mehta S, Mokdad A, Bhutta ZA. Global and regional trends in the nutritional status of young people: A critical and neglected age group. Ann N Y Acad Sci. 2017;1393(1):3-20. https://doi.org/10.1111/nyas.13336 PMid:28436100

11. Tamrin A. Edukasi pedoman gizi seimbang (PGS) terhadap pengetahuan dan sikap siswa SMP Negeri 1 Barru. Med Gizi Pangan. 2019;26(2):185-9. https://doi.org/10.32382/mgp. v26i2.1028

12. Ekundayo EO, Akinlade $\mathrm{O}$, Ewulo OR. Health information provision for the vulnerable orphans in Ogun State, Nigeria. Libr Philos Pract. 2019;2(1):1-12.

13. MacKenzie-Smith L, Marchi P, Thorne H, Timeus S, Young R, Le Calvé P. Patient preference and physician perceptions of patient preference for oral pharmaceutical formulations: Results from a real-life survey. Inflamm Intest Dis. 2018;3(1):43-51. https://doi. org/10.1159/000493346

PMid:30505842

14. DiSantis KI, Birch LL, Davey A, Serrano EL, Zhang J, Bruton Y, et al. Plate size and children's appetite: Effects of larger dishware on self-served portions and intake. Pediatrics. 2013;131(5):e1451-8. https://doi.org/10.1542/peds.2012-2330 PMid:23569096

15. Mak AH, Lumbers M, Eves A, Chang RC. The effects of food-related personality traits on tourist food consumption motivations. Asia Pac J Tour Res. 2017;22(1):1-20. https://doi. org/10.1080/10941665.2016.1175488

16. Mallongi A, Natsir MF, Astuti RD, Rauf AU, Rachmat M, Muhith A, et al. Potential ecological risks of mercury contamination along communities area in tonasa cement industry Pangkep, Indonesia. Enferm Clín. 2020;30(4):119-22. https://doi. org/10.1016/j.enfcli.2019.10.054 PMid:32545027

17. Mallongi $A$, Limbong $E$, Naiem $F$, Ishak $H$, Basri $S$, Saleh $M$ et al. Health risk analysis of exposure to mercury $(\mathrm{Hg})$ and cyanide $(\mathrm{CN})$ in Kayeli village communities Teluk Kayeli district Buru Regency. Enferm Clín. 2020;30(4):427-30. https://doi. org/10.1016/j.enfcli.2020.03.007

18. Benton D. Portion size: What we know and what we need to know. Crit Rev Food Sci Nutr. 2015;55(7):988-1004. https://doi. org/10.1080/10408398.2012.679980

PMid:24915353 